\title{
THE ROLE OF RELIGION EDUCATION DEALING WITH RADICALISM: Madrasah is a Religious-based Character Education Model
}

\section{Supa'at}

STAIN Kudus

e-mail: supaatkudus@yahoo.com

\begin{abstract}
The purpose of this paper is to elucidate and to look for efforts to deter spreading radicalism phenomena in the world. The terror attacks have engulfed many part of the world and blamed on radical and extremist groups who have put Islam and Muslim on world attention. Indeed the terror attacks have heightened a growing sense of Islamophobia. And therein is the paradox! Should the activities and "sin" of individual Muslim(s) or group $(s)$ be visited on an entire community and relegion? As a consequence Islam is perceived as religion with a predilection to conflict, aggression and violence, peace is the kennel of Islamic religion and one of its significant ingredients. Many factor causing these phenomena, one of them is misunderstanding and misperception on Islamic norm and teaching they had got. It must be wrong in the process of norm transferring and teaching-knowledge, and values. Education is the rational answered and effort to prevent and deter radicalism phenomena. Compatibility of goals, matter, method of teaching with development (especially moral development) of student will produce internal power as a result of educational process. Madrasah as a varian of education or Islamic aducation empiricly has been contributed shaping moderat muslim, known now as Islam Nusantara.
\end{abstract}

Keywords: madrasah; islamic education; radicalism;

misperception; moderat 


\section{ملخص البحث}

تهدف هذه الورقة التوضيح والبحث عن جهود لردع انتشار ظواهر التطرف في العالم.

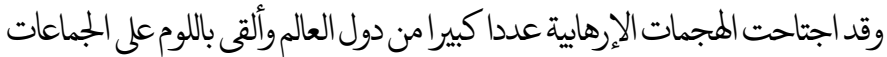

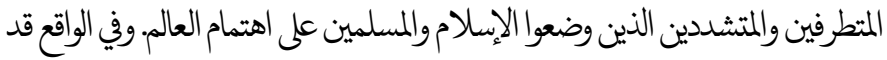

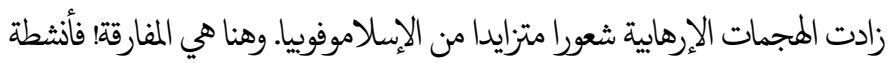

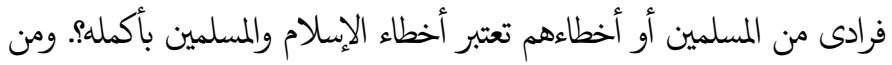
العوامل المسببة لمذه الظواهر، هو سوء الفهم على القاعدة الإسلامية وتعاليمه الصحيحة.

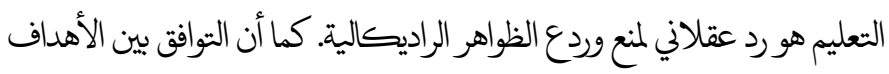

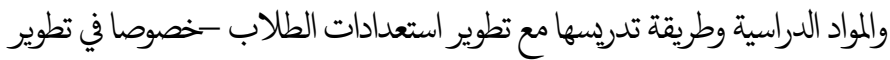

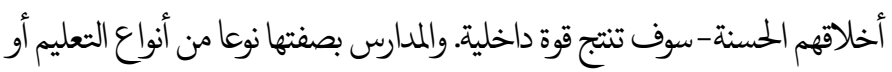
التربية الإسلامية قد ساهمت في تشكيل الإسلام الوسطي، والذي يعرف الآن باسم إسلامنوسانتارا.

الكلمات المفتاحية: التعليم، التطرف، الوسطية 


\section{Preface}

Whether we like or not, the phenomenon of extremism, radicalism and violence that has been occurred in the world at the moment is always associated with or even on behalf of religion. Religion's symbols and terminlogies have always been a vital element in action that they are doing. Religion seems to be a fertilizer that nurtures those understanding and belief, even it could be an instrument to justify violent deeds that they are doing. Whether it is happened by chance or not, by desingned or not, reports related to religious violence and extremism has always been on part of the earth where the revelation was revealed and/or divine religions, namely region of Middle East. However we could find religious violence in other areas, but when it is traced back the origin of these ideologies, it will be found that the source "asian water" is from Middle East area. Some of extrimist organizations such as Thaliban, al-Qaeda, Boko Unlawful group in Negeria, and ISIS (Islamic State of Iraq and Syria) which nowadays becomes center of world's attention, are example of tought or movement of extremist-radicalist which goes under the name of religion. Of course, There are a lot of similar toughts and movements in a number of countries with different name but its ideological ground and essence is same; eksklusivisme, extremism, radicalism or known today with the takfiri ideology (judging other people or groups that have disagreed with them as infidel, eventhough they are Muslims).

What is wrong with their understandings and actions? If violence, killing, robbery, even raping unguilty women are lawful on beliefs. So what makes them different from mafia or criminals groups who are in various countries? In such condition, Of course there is something wrong with their minds or their ways of thinking which lead to a deviating view and misleading thoughts. When we observe it, we will aware that the birth of such understandings could not be released from the social, political, and economic context, even mainstream thoughts, existing in a particular country, are really influenced to kind of ideology. The paper will not elucidate background of the birth such extreme and radical thought, but it will focuse more on how to tackle or what kind of efforts that we can do to overcome -reduce even eliminate- religious radicalism. Taken Efforts by some governments in 
various countries to overcome misunderstandings or the violence more likely on the use of force (law enforcement). Although this way is really needed, we should know that the fact shows violence approached by other violence will only give birth to a new violence, which could be more and more serious. Various facts show, their belief or ideology has not been easily changed by a repressive manner. If the punishment of body, and even death is not made them afraid and does not give deterrent effect, even it become ideal because it was considered as being martyred dead "syahid".

It needs comprehensive and simultaneously efforts with an emphasis on preventive approach to tackle the problem, for instance through reunderstanding religions teaching or deradicalitation for various religious understanding turning away from the essence of Islam itself. On young generations need to gain from the side character and religious, it is expected to grow internal power who are able to select and/or ideologies warding off the entering a new not in accordance with essence and spirit Islam that always taught peace for all (rạ̣matan li'l-'âlaminn). Although the results is in the long term, which means the process requires a long period of time, education is more effective way to overcome this phenomenon.

If the problem has rooted on their understanding of religion, religious education is an effective method to curb extremist and radicalist ideologies. In the context of process, the religion as learning materials should be given in the level and a good way so that the results of learning is in line with what we expected. Emergence of these extreme ideology actually was due to wrong understanding and the perception, so it leads wrong beliefs and actionscontrary to religious proselytizing religious teachings (Islam). A mistake could be occurred from the teachers as the giver or the one who conveys teachings (sender) and his disciples as the recipient (receiver). Thus, the process religious education need to pay more attention to students condition and the context with the materials and the way that is in accordance with the context of space and time-dimensional (local wisdom - bi'l-hikmah). With this conceptual framework of religious teachings, it is trully expected that values of religion received by the students will give birth to a religious tolerance that is true peacefulness and rạmmatan li'l-'älamīn. 


\section{Education Builds and Shifts Perception}

Based on process outlook, educational activities are basically a process of conveying "information" to a large number of learners. It is expected that received information was able to give understanding, to shape perception, to grow confidence and to bring a productive action to learners theirselves and others. Thus, all of definitions about education have a substantive meaning which always referred that is to transfering information process (knowledge) with its output is to build possitive attitudes and behavior (useful and meaningful knowledge). To achieve that goal, at early stage or education process must be able to convert the knowledge received by students into an understanding or positive perception on information that was received. It is Because human action (the attitudes and behavior) basically always and must be based or started from a belief. One's belief is gained or composed from perception of an object that received or caught by human's sesnse. We could simplify that the actions of a person is very determined or depending on the information (knowledge) that he received, Even one's faith to anything will always begin from positive perception, including beliefs of religion teaching. When we look with communication point of view, an effectiveness is determined by the three main variables, namely information giver (sender), information recipients (receiver), and material of communication itself (contain). From this perspective, education, learning and teaching activities are basically a process of transferring information (knowledge and vallue) to the students with the purpose to make what they received become usefull and meaningfull information for himself and others, now and in the future.

Perception is one of the most important of psychological aspects for human being in responding the presence of various aspects and responses around them. A number of experts defined perception in various ways and meanings, yet their essence meanings are similar. In Indonesian dictionary ${ }^{1}$ it is stated that the word 'persepsi' (originally from English perception) means; response (acceptance) directly from something. One's knowing process of anytyhing is through five senses. Perception is the process whereby the brain

${ }^{1}$ Departeman Pendidikan Nasional, Kamus Bahasa Indonesia (Jakarta: Balai Pustaka,1995), p. 759.

Tawasut - ISSN 2338-042X - Vol 5, No 1 (2017) 
interprets the sensation it perceives, giving them order and meaning. While Anita E. Woolfolk and Lorraine McCune-Nicolich, ${ }^{2}$ stated that perception refer to the meaning we attach to the information receive trough our senses. This meaning is constructed partly from objective reality and partly from the way we organize the information. It is important to grasp that the eyes merely look and brain sees. And what the brain sees may be determined as much by cognitive structure as by the information from the world outside. We perceive what the brain decides is in front of our eyes.

Those definitions can be outlined that the important elements of perception is sensing or sensation, which is a stimulus that was received by individuals through a receptor namely senses. A sensory organ are the link between individuals with the rest of their outside world. Perception is a stimulus cought by individuals trough their sense, organised and interpreted so individuals realize and understand about what they saw, heard, felt and so on. The term sensation refers to the basic, immediate experience that start with psychological stimulation. By perception, we generally mean the interpreted, elaborated, organized experience based on the "raw material" of sensation.

From explanations above, it can be drawn a common understanding that perception is essentially a process that started from the vision to be formed response in the individual who is aware everything in their neighborhood through the senses belonged to them. In order to produce positive action and attitude, perception must be a constant and consistent. One of the important variable that able to make consistent perception is experiences. Perception ${ }^{3}$ is essentially a process when individual control and interpret sensoric impressions to give meaning for their environment. Individual behaviors often are based on their perception about facts, not basen on facts threirselves. Factors that infuenced perception building, in general, can be summed up into two categories; internal factors ${ }^{4}$ and external factors. ${ }^{5}$

\footnotetext{
${ }^{2}$ Woolfolk, Anita E. and Nicolich, Lorine Mc Cune (Educational Psychlology for Teachers (New Jersey: Prentice-Hall Inc. Englewood Cliffs. 1980), p. 197.

${ }^{3}$ Miftah Toha, Perilaku Organisasi Konsep Dasar dan Aplikasinya (Jakarta: Grafindo Persada, 2003), p. 154 .

${ }^{4}$ Internal factor is the factors that could be found in their individual, which includes several things such as: (1) physiological factors . Sense capacity for getting perception on everybody is different, so interpretation of environment is also various; (2) attention factors. Energy one different destinations so 
How could a perception be established? According to Miftah Toha, ${ }^{6}$ formation of perception process has been based on several stages, namely: (1) stimulus or stimuli, (2) registration, is a phenomenon which physical mechanism that is either sensoric through a human sense that belonged to man. One can hear or see information delivered to him, then to register all the information delivered to him, and (3) interpretation, is process of giving meaning to economic stimulus plan that it receives. This process is very much depends on how to depth. According to Bimo Walgito, ${ }^{7}$ there are three factors playing a fundamental role in the establishment of a perception, namely: (1) perceived objects, (2) sensoric instrument, nerves and its stucture and (3) attention.

In natural way, a individual capacity (innat) in comprehending information (input) from the outside has differentiation, therefore perception has a subjective characteristics. The difference gives birth to interpretations that may be different between an individual with others even though objects that observed are similar at the same time. Thus perception is a process that individual gives response, meaning, image, or interpretation toward what he has seen, heard, or be felt by his senses in attitude form, opinion and behavior. Because of its subjectivity, basically a perception is choice to think positively

that attention to a person is also different and this will affect perceptions of an object; (3) interest factors. Perception of an object vary depending on how much energy or perceptual vigilance that are used to sense. Perceptual vigilance is a tendency to lead a person based certain type of stimulus or can be called as interest; (4) The need for the same direction factor. These factors can be seen from how strong individual looking for these objects or a message to answer in accordance with himself; (5) memories and experience factor. Experience can be said that it is depending on memory in the sense that what extent one can remember the events past to stimulation in the sense understand a broad; and (6) mood factor. Emotional state affected on a person, mood is to show how a person feels at a certain time which can affect how a person receivs, reactes and rememberes.

${ }^{5}$ External factor referred to a character of environment and objects involving within. These elements could change a person's point of view about the world around him and affect how he feels it or accepts it. These factors includes: (1) size and placement of objects or stimulus factor. this factor said that the greater relationship to object, the easier to understand. This structure will influence perceptions individuals and to see size an object individuals would easier get attention in turn shaping perceptions; (2) The color of objects factor. objects that have more light will be more easily understood and perceived than those have less light; (3) uniqueness and stimulus contrast factors. Outer Stimulus which its appearance with background and around a totally outside putative individuals that another will attract much attention; (4) intensity and the strength of stimulus factor. Outer will give more meaningful if more attention to that which is only seen. Strength from a stimulus from an object that can affect perceptions; (5) Motion factor. Individual will give attention to objects that give the movement in his sight range compared with quite objects.

${ }^{6}$ Miftah Toha, Perilaku Organisasi Konsep Dasar dan Aplikasinya , p. 145.

${ }^{7}$ Bimo Walgito, Pengantar Psikologi Umum (Yogyakarta: Andi Offset, 2004), p. 70. 
or negatively. As a result a perception is not always similar with the reality as it is. There is a possibility that a person's perception is right and there are also likely one's perception is wrong. To know (test) truth perception ways that can be taken among others, through to get more information about things, it can be in the form to communicate more on the other parties that are related. It is very unfair and one as a result when we only considered someone or something partially, for instance by only seeing his face without having communication and adjust us to judge someone with a certain attributes. The phrase here is relevant to avoid a wrong decision because of an an adequate perception. "Don'tjudge the book by its cover"

From the explanation above, it can be concluded that a person's perception of an object can be set up or to be changed. As a process, educational activities have been considered a success when it is capable of forming perception either positive/negative perception or change it into a positive leading to right mindset and attitude good behavior or good character. In other words education process must be able to spread atmosphere and any matters to make it possible for positive perception (husnu zan) and losing negative perception (su'u zan). Therefore, the education and/or learning namely pedagogy competency must guarantee the process gains for ensures the positive perception that is consistent. To ensure that education in accordance with the goal was established, the lesson scenarios that can be must present material and presentation that are compatible. Compatibility between the goal, materials, ways and/or strategy, the media, and the learners environment with variable to epicenter that must be paid attention in the process of learning.

In case of arising extreme phenomenon, radical attitudes and violent behavior on behalf of religion, one thing is certain that there has been misunderstanding and mis perception toward religion teaching, so it has led not productive religiosity. ${ }^{8}$ This mistake is caused some factors, and the most

\footnotetext{
${ }^{8}$ Religion is the source of values or teachings that comes from Allah (revelation) through his messengers, who is transendetal. While religious tolerance is an action considered as a procedures form or response to religious teachings. in other words religiosity is referring to a series of activity, behavior and belief in order to carry out the essence of religion in real life for them. Because it is factual and empirical phenomenon, religiosity is behavior or action of people as a product of their understanding and perception upon religion teaching or doctrine. Therefore, even though the text of teaching
} 
important is due to religion that was not understood fully and comprehensively, but it was only understood partially in accordance with the necessities of subjects. Eventually, There are many exclusive and narrow fanaticism attitude that actuaaly is at odds with essence and spirit of Islam and rahmatan lilalamin. From the education point of view, the emerge of extremism, radicalism and violent ideology was affected by causes, some of them are: (1) Material of religion teachings, given to students, are not in accordance with their readiness and mental maturity (moral development). (2) learning methods and strategies used by teachers are not proper with materials and goal of religion learning, and as a result religion only become a knowledge. For in-oriented pedagogis, teaching in the constitutional cognitive learning different with attitude-oriented learning. Although it must be understood that this distinction is not absolutely happen because each domain is inextricably linked. (3) narrow understanding and knowledge about Islam rahmatan lil alamein. (4) limited teaching materials and religion learning time caused unsufficient understanding of religion belonged to students. (5) Religion was seen merely as a doctrin with vertical dimension, and less based on horizontal dimension. These are the things among the causes less than a foundations understanding the learners religion so that it is easy to understand and influenced new ideology that was accepted by students outside the school. Their stronger and truth understanding of religion is will be able to become the antidote for ideas or new idelogi that was not according to nationality concept. And that is not less important of all of the factors is the influence of the environment. In this era that is where open access to information can be from various sources like at this time, the students learn from the neighborhood self-assistance very easily and cheap where various information is available.

Based on an explanation above, in order to address and to prevent the false perception on religious teachings, we need to seek or formulate an educational model that gives a balance between our wordly need and spiritual need. Religion teaching material should be proportionally given to

(nash/revelation) is the same, but it could be different behavior and attitude displayed by people, at least procedure or zāhiriyyah -empirical appeareance (Muslim A. Kadir, 2011). 
students according to their needs. It is taught with right method and convenient atmosphere learning, and taught by professional teachers. These conditions will support to build a religious balance with necessities of learners. Madrasa educational system is an example of religious-based character education that equally give between general (wordly) knowledge and religion knowledge. Such Models of education is expected to be able to provide the participants' knowledge of religion which is established as a foundation for positive attitudes and behavior as good citizen.

\section{Character Education}

As a universal phenomenon, the common goal of education substantially is: "... to help young people become smart and to help them become good". the output of Education must include two things, first is smart (cleverness) and good behavior (righteous deeds). The ultimate goals of education is how to facilitate student to be good citizens". In his words Martin Luther King (1948) stated, "... which we're must remember that "intelligence is not enough. Intelligence plus character - that is the goal of true education." Without any support from a strong character and personality, intelligence is just like a sharp knife that can be used beyond its allocation or basic function. If this has been happened, intelligence would not produce benefit for himself and others. To provide all of those, it seems very important to reconstruct a system and good education, because the fact is that our education has "failed to form a human as mandated by the national education goals (faithful, fear God, and excellent moral standards). This failure can be seen from daily facts an intolerant behavior, exclusive attitude and radical extreme, and various other aside destructive behavior that seems more increased in quantity and quality. One of the efforts can be carried out by the students to form a character among others is by improving the quality of teaching and function of subjects that is full with the materials of ethics and moral values high moral standards. In this religious education, good and material and learning system needs to have serious attention, not only by religion teachers but all these elements school madrasah comprehensively. 
As a concept, various definition of character always referred to response of a question "how 'good' a person is"?9 In other words a person who shows a high-quality and it is hoped by society and a person were considered to have a good character, in the context education so it is to be the aim of education (good citizen). As it is said by Suyanto ${ }^{10}$, character is a way of thinking and how to walk, to the characteristic each individual to live and work together in family, community, nation and state. Individual character is individual who can make decisions and ready to widen responsibility as a result of the decision he created. According to Thomas Lickona: 11 "character is a reliable inner disposition to respond to situations in a morally good way ".... Character so conceived interelalted has three parts, moral knowing, moral feeling, moral or deviant behavior In this sense, characters moral standards (good character) includes knowledge of good, a commitment (intention) to good things, and was actually good. In other words, characters refers to a series knowledge (cognitive), attitude (psychomotor), and motivation (intention), and behavior (or deviant behavior) and skill (skill). If his explanation can be simplified by us which essence of character is identic with the good morals, because character is universal values of human behavior which covers the

\footnotetext{
${ }^{9}$ The character; attributes, habits psychological, moral or outstanding traits that distinguish one with another. Character can also mean letters, numbers, space, the symbol which can be raised on the screen with keyboard. (Kamus Besar Bahasa Indonesia, 2008: 682). When the word karakter addressed to those with a prefix "ber" (ber- karakter) means the one who has personality, behavior, attitude. With such understanding, word character is identic to personality or akhlaq (moral). The word akhlaq moral in daily use often identified as character, ethics and moral values. Akhlaq comes from the Arabic with plural form " al-khuluq " which means outstanding traits, behavior, nature, or habits (Ya'qub Hamzah, 1988:11). According to Ibn Maskawih akhlaq means soul motion that encouraged people to do with no mind consideration. According to al-Ghazali, akhlaq is a character that lied in a soul from and it appears easily, without a long mind consideration (Rahmat Djatmika: 1996: 27). in Indonesian word treasures, word which is equivalent to that means akhlaq is moral and ethical. These two words often aligned with outstanding traits, good conduct, governance polite manner, or polite (Faisal Isma'il, 1998:178). In essence conceptually said ethics and morals have understanding was similar to, namely talk about their works and human behavior observed from the perspective of a good values and principles. But in the application of ethics more theoretical philosophical as a reference to examine value system, and moral is practical for the measure to assess what will be done by a person (Muka Sa'id, 1986: 23-24). Ethics looked behavior in more universal view, while moral looked it locally. To apply akhlaq, ethics, or moral values buried in a deep soul, a science emerged the so-called akhlaq Education, ethics Education or moral Education.

10Suyanto, Urgensi Pendidiklan Karakter (Jakarta: Direktorat Jenderal Manajemen Pendidikan Dasar dan Menengah:, 2009).

11Thomas Lickona, Educating for Character: How Our School s can Teach Respect and Responsibility (New Yok, Toronto. London. Sydney, Aucland: Bantam Books, 1991), p. 21.
} 
entire human activity, both in order to build relationship with God, fellows, human beings, as well as his neighborhood, which was realized in minds, attitudes, feelings, words, and works based on religious norms, law, governance polite manner, culture, customs and traditions.

Meanwhile, the word education as a concept by some experts defined in various words eventough they have substantive definition, that is changes or transformation process From unkown to know, from bad to good/better, from incompetent to competen/skillful. In the term of Douglas M. Windham, ${ }^{12}$ these changes or educational outputs include: cognitve achievemen (cognitive domain), improved manual skill (psychomotor domain), atitudinal and behavioral change (affective domain). ${ }^{13}$ In other formulation that is quite different, Noeng Muhadjir ${ }^{14}$ formulated education as a such interactive relation between giver and receiver to achieve a good goal trough a positive way in a positive context. On the basis of this interpretation, education has three functions: (a) to nurture students' creativity as receiver. (2) to enrich cultural treasure of human being, to enrich values human and god. (3) to prepare productive labor.

Those definitions of education implied that the universal purpose of education is to build students attitude and personality, started from the process of the transmission of information and values internalisation. This means that without giving an additional word "character", in fact the aim of education is the students character buildingf. As definition character educa-

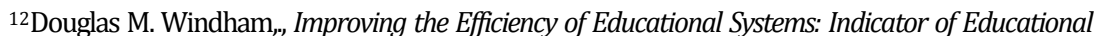
Effectiveness and Efficiency (New York: United State Agency for International Development Buereau for Science and Technology, 1990).

${ }^{13}$ In the cognitive domain, educational goals include and connect with: “...recall or recognition of knowledge and the development of intellectual abilities and skills". In the affective domain; “... changes in interest, attitudes, and value, and the development of appreciations and adequate adjustment". And in the psychomotor domain; "... the manipulative or motor skill area - improve manual skills" (Bloom,1956: 7) . going beyond these taxonomy, Romiszowski (1984: 35) added one's domain, which called by the missing domain, he termed it interactive skills. Actually, classification of Romiszowski was not much different from Bloom's taxonomy, et al. According to Romiszowski (1984: 42), the aim of education categorized into four, with an emphasis on the skills, namely: (1) Thinking or cognitive skills, (2) acting, physical or motor skills . (3) Reacting to things, entire or people in term of values, emotions, feeling self-control skills ). (4) Interacting with people in order to achieve some goasl, such as communication, education, acceptance, persuasion, etc. (Skills in controlling others ).

${ }^{14}$ Noeng Muhadjir, Ilmu Pendidikan dan Perubahan Sosial: Teori Pendidikan Pelaku Sosial Kreatif. (Yogyakarta: Rake Sarasin,1990), p. 4.
} 
tion formulated by Ratna Megawangi; ${ }^{15}$ "... an effort to educate children in order to take decisions wisely in their daily life and inpleement it in daily life, so can give a positive contribution to their surroundings. The Other defined, Character education closely refers to teaching children in a manner that imparts one or more positive character qualities -such as to make them moral, civic, good, well mannered, non-bullying, healthy, critical, successful, traditional, compliant socially acceptable. ${ }^{16}$ In the term of Fakry Gaffar, ${ }^{17}$ character education is a transformation process of life values to be grown in individual personality that it might be embedded in man behavior" In school setting, according to Dharma Kesuma et.al ${ }^{18}$ character education is teaching that direct on strengthening and development on children as a whole based on a certain values that are referred to by the school". This Definition if simplified then, character education is "the process of establishing based on certain values". In the context of Indonesia's education sector the values that are referred to as a reference for education is the teosentris and anthropocentric value.

Problem now is how these values can be planted effectively in students themselves? Of course it needs transfering process and values internaslisation that are compatible between the goal, materials and methods with the situation either physical or non-physical, especially moral capacity (moral development) of the students. Related with this issue, it may be relevant to note a development of moral levels presented by Lawrence Kohlberg's. ${ }^{19}$

\footnotetext{
15Ratna Megawangi, Pendidikan Karakter: Solusi yang Tepat untuk Membangun Bangsa (Bogor: Indonesia Heritage Foundation, 2004), p. 95.

16http//www. Wikipedia Encyclopedia 2010).

17Fakry Gaffar M., "Pendidikan Karakter Berbasis Islam”, Yogyakata: seminar papers (8-10 April

${ }^{18}$ Dharma Kesuma, etal, Korupsi dan Pendidikan Anti Korupsi (Bandung: Pustaka Aulia Press, 2011), p. 5.

${ }^{19}$ Accoding to Kohlberg, moral development divided into three levels: (1) preconventional, where judgment is based solely on a person's own needs and perception, and on physical power of the rule makers. (2) Conventional, where the expectation of society and law are taken into account; and (3) Postconventional, where judgment are based on principles that go beyond specific laws. Each of these three level is than divided into stages: Level I. Preconventional; 1 . Obedience only because of fear of punishment; deference to power; 2. Meeting own needs and making "fair trader"; the morality of reciprocity. Level II. Conventional. Judgment based on social expectation and the belief that one must be loyal to one's family, group, or nation and maintain the social order. 3. Good behavior is the behavior that pleases or help others; the good boy/girl orientation. 4. Judgment based on respect for authority and feeling that one must do one's duty, maintain the social order for its own sake, and promote "law and
} 
Specifically in the context values learning, it is very urgent to use a systematic education and teaching model and a holistic approach and integratiion. With the method this model of teaching or are expected to grow consciousness that people want to do on a good because he love with on this good.20 Implementation of character education in a systematic, on, and synergistic a child will be intelligent affection and emotionally (emotional and spiritual intelligence). This intelligence is important in preparing their children to meet its future, because a person will be more easily and successfully face all kinds of life, including facing challenges to succeed academically. It is wickedly essence and purpose of character education. As formulated by Thomas Lickona, ${ }^{21}$ the aim of character education is:"... to develop student socialy, ethically and academicly by infusing character development into every aspect of school culture and curriculum. To help student develop good character, wich include knowing, caring about and acting upon core ethical values such as respect, responsibility, honesty, fairness and compassion". Such Concept and educationall model can be viewed from its function that it olud be name as holistic education, becouse"... the highest function of education is to bring about an integrated individual who is capable of dealing with life as a whole".

The educational setting at schools, character education aimed to: (a) strengthen and develop the values of life that is considered important and necessate for learners, so their personality become unique as the developed values; (b) correct the learners behaviour that are not accorded with the values developed by schools; (c) build harmonious connection that with families and communities in role-playing responsibility of the character education together in the same time.22 Thus, in the school context, character

order". Level III. Postconventional. Judgment based on principles that go beyond specific laws or authority of the people who make the law. 4. Rules based on social consensus; feeling that rule can be change if there is a good reason; valuing of general individual rights agreed upon by the whole society. 5 . Decision based upon self-chosen ethics principles. The principles are abstract and universal, such as justice and equality. Woolfolk, Anita E. and Nicolich, Lorine Mc Cune (1980). Educational Psychlology for Teachers (New Jersey: Prentice-Hall Inc. Englewood Cliffs, 1980), p. 103-104.

20Masnur Muslih, Pendidikan karakter: Menjawab tantangan krisi multidimensional. Jakarta: Bumi Aksara., 2011), p. 78.

21Thomas Lickona Educating for Character: How Our School s can Teach Respect and Responsibility (New York: Bantam Books, 1991), p. 21.

${ }^{22}$ Dharma Kesuma, et.al, Korupsi dan Pendidikan Anti Korupsi, p. 71. 
education addressed tor: (a) develop the potential to be more cautious when the good, good-minded, and behaves well; (b) strengthen and build on the multicultural; (c) increase civilization that is more competitive in associating world. Because the purpose and function, character education must be done through various kinds of education, begun from family education, formal and non-formal educational units, civil society, political community and government, business community, and media.

Related to values that must and will be developed, Azyumardi Azra ${ }^{23}$ proposes a nine pillars of character that comes from universal values, they are: (1) characters of loving God and all his creation; (2) self-reliance and responsibility; (3) honesty, truthful and diplomatic; (4) respect and Compassion; (5) generous, helpful and sense of mutual cooperation; (6) self-confidence, and hard-working; (7) leadership and righteousness; (8) good and humble, and; (9) characters of tolerance, peace, and unity. Ninth pillars of character could be taught systematically in models of holistic and integrative education, among others by using this method knowing the good, a feeling that I the good, and the acting the good. Knowing the good can easily be taught because knowledge is cognitive. After knowing the good must be grown feeling loving the good, namely how feel and love a credible engine for good that can make people always want to do anything good. So growing awareness that, people want to do on good because he love with on it. After getting used to do good, then acting the good, turned into a habit. In line with the opinion, Michael Josephson, presents six values as well as pillars of ethics and character education, namely: (1) Trustworthiness, (2) respect, (3) Responsibility, (4) Fairness, (5) Caring, and (6) Citizenship. Furthermore six pillars, there are eleven principle that effectiveness of implementation must be held by for character education, namely: (1); Promotes core ethical value; (2) Teacher student to understand, care obout, and act upon these core ethical value; (3) Encompassing all aspects of school culture; (4) Fosters a caring school community; (5) 0ffers opportunities for moral action; (6) Support academic achievement; (7) Develops intrinsic motivation; (8) Includes whole-staff

\footnotetext{
${ }^{23}$ Azyumardi Azra, Surau: Pendidikan Islam Tradisional dalam Transisi dan Modernisasi (Jakarta: Logos, 2003).
} 
development; (9) Requires positive leadership of staff and students; (10) Involves parents and community members; (11) Assesses results and strives to improve. ${ }^{24}$

The essential matter which should be considered to lead a success character education is that education must have been given in a systematic manner since childhood (golden age), because of some reasons; (1) the pereode was very determined development capability and potential for children in next periode, (2) reversibility of adult intelligence has already happened when they were children around 4 years old. Therefore, deservedly character education should be started from family meleu, which is the first environment for character growth of children. there are some factors that Empirically caused failures for children at school. These factors are not located in brain intelligence, but on the character, such as: the confidence, ability to work together, ability to interact, ability to concentrate, sense of empathy, and ability to communicate. ${ }^{25}$ Similar opinion has been put forward by Daniel Goleman ${ }^{26}$ that a person's success in the community, actually was influenced 80 percent by emotional quotient, and only 20 percent is determined by intellectual quotient (IQ). Children who have problems of emotional quotient will challange learning difficulties, interaction and not able to control their emotion. Children with these problems could be observed since a pre-school age, and if it is not treated immedietly, it will grow with them until they are adult. In the contrary, teenagers who have strong character will be avoided from common problems faced by young people that due to originate from intolerant, exclusive, akstrim attitudes etc.

\section{Madrasah (Islamic School) in Indonesia}

\section{Meaning and Short History of Madrasah}

As one of variants the educational institution and Islamic education in Indonesia, existation of madrasah cannot be separated from historical

\footnotetext{
${ }^{24}$ http// www.chracter.org. 2009: 152. 35.

25Joseph Zins, et.al., Emotional Intelligence and School Success. (New York: Phi Delta Kappa, 2001), p.

${ }^{26}$ Daniel Goleman, Emotional Intelligent (Kecerdasan Emosional), translated by T. Hermaya (Jakarta: Gramedia Pustaka Utama, 1997), p. 21.
} 
development of Islamic da'wah in Indonesia archipelago. This fact made madrasah has been being apperciated until recentdays as "religion schools" or "religious schools". The establishment of madrasa considered as educational institutions in the context of education history in Indonesia, has aimed not only to to enhance effectiveness and capacity lesson but also to respond a Dutch colonial government policy that began to introduce formal education system which was more systematic and well-ordered, which is in fact many children from Muslim families study in educational institutions. The policy of colonial government was not be separated from christian missionary and efforts to gain cheap labor to meet colonial interests.

The independence era, based on regulation Minister of Religious Affairs Number 1, 1952, school was formulated as the education place containing education and islamic knowledges became main lesson. In its development, according to regulation Number 2, 1989, described in the Government Regulation Number 29, 1990 and the Decree of the Ministry of Religious Affairs Number 370 and 373 1993, the school has a new high-definition as public schools characterized with Islam, namely: "education based on teachings of Islam and education surrounded by religious atmosphere". This is obviously different from previous status, which madrasah known as religious educational institutions that only teaches religious sciences, science generally if there is only as a complement or additional. Institutional form madrasah as a formal consisted of three levels, namely Madrasah Ibtida'iyah (MI), Madrasah Tsanawiyah (MTs), and Madrasah Aliyah (MA). Respectively equivalent and aligned with educational institutions elementary school, junior and senior high school students. The regulation was the whole process of development of education which consists of institutions, the structure, the curriculum, materials and other basic concept is on a single package, as has long been fought for a long time before independence. To meet the demands these regulation, especially article related to the curriculum, Minister of Religious Affairs issued Decree Number 371, 372, and 373, 1993 about The curriculum of MI, MTs and MA. This decision was born madrassa syllabi called with The curriculum of madrasa (Islamic Schools) 1994. The curriculum 1994 composition portion and time for religious education materials only more or less 10 percent, while in the curriculum 1984 30\% is different from previous curriculum. 
In colonial era, the Dutch did not only not admit educational institution that established by the group indigenous Muslims, but also with contempt institutions (education) Islam. Because of negative perception, then all of the policies taken by the Dutch related to education always discriminative in many things. Model policies such as this is carried to independence era, which among other things gave birth to dikhotomi and dualism in the management of education, where within the education system in Indonesia, some schools that are administered by the Ministry of Education and school which is managed by the Ministry of Religious Affairs. Each one runs its own, and madrasah (graduate school, the victim because) order is not equal graduates are considered to be/equivalent with school graduates. This fact encourage SKB bringing three ministers in 1975, which its hiden mission is recognition of equality of state school and madrasas graduates.

The law No. 02, 1989 then was amended by regulation number 20, 2003. it does not only strengthen existence of madrasah in judicial and political aspect, but also bring madrasah to sub-national education system and eliminate dualism education system in Indonesia. In other words, the educational institution madrasah have to get the position that was fought, that is common and equality. As an educational characterized with Islam, and schools have comparative advantages, because there is a significant emphasis on education and religious moral (morality/character), besides of course in mastering subjects general (seculer science). With the marketplaces madrasah has an opportunity to become the "alternative education" in the anxiety community will be a lack of understanding the values of religion and the negative behavior, and intolerant behavior, moral decadence in the daily life.

\section{Goals and System of Madrasah Education}

The core and essence of Islamic education is islamic da'wah. This means that activities and Islamic education process are process of Islamic da'wah itself. Therefore, historically format Islamic educational institution at the earliest age was as similar as Islamic da'wah, such as hallaqah. From goal view, madrasah as a variant of Islamic educational institution format, of course its goals are similar with the aim of da'wah Islam. As a form transfomasion and formalisation of hallaqah system, madrasah as an educational 
system adopted Western classical education (schooling process). This happened because of hallaqah system and Islamic boarding schools are considered no more compatible to accommodate the needs of education for people. Thus, it was not wondered when the systems of education in madrasah was not different with home schooling education model, the difference was only on the core of learning materials. As Islamic education institutions, therefore the aim of education schools is the same with the aim of Islamic education as understood wholly contained in the concept ta'lim, tarbiyah, and $t a^{\prime} d \bar{l} b .{ }^{27}$ According to Imam Musthofa and Ally, ${ }^{28}$ education (Islam) is a process to form a knowledgeable Muslim with sroh belief and have fear of Allah the Almighty. With an emphasis on "inheritance", Zuharini, et al. ${ }^{29}$ formulate education (Islam) is this process of inheritance and cultural development man who comes and in accordance with this the teachings of Islam as it is written in the Qur'an and elucidated in exact proscriptions. meanWhile according to Ahmad commentaries, ${ }^{30}$ education (Islam) is clear direction given by a person to a person that he has developed in a maximum in accordance with the teachings of Islam. Or, if it abbreviated, direction to understanding to the person so that it would be a Muslim as deep as possible.

\footnotetext{
${ }^{27} \mathrm{~A}$ ta'lim term interpreted by experts as a process to give knowledge, understanding, responsibility and embedding mandate, so that a self purification is happened to soul of man (tazkiyyah) from every dirt and make himself in a ready to accept the wisdom and learn everything that is notyet known and will be useful for himself (Jalal, 1977:14). As a concept, al-tarbiyah, has some of the elements: (1) maintain children consciences (fithrah) and strenghten it with full attention, (2) nurture miscellaneous talent and their readiness, (3) directs disposition, talents children toward a better and strive for perfection, and (4) do all of these elements gradually (Hamzah, 1996: 9). Similar opinion has been put forward by Abdurrohman al-Bani (Maksum, 2004: 14), that the word tarbiyah contains three connotation elements: (1) to keep and maintain children, (2) to develop talent and the potential for children in accordance with their special characteristic, and (3) to direct the potential and talent that was good and perfect. The term ta'dīb meaning knowledge ('ilm), teaching ( $t a ' l i m$ ) and educating (tarbiyah), so it can include some education aspects that is interconnected with true essence education, such as 'ilm (knowledge), ' adl (jutice), wisdom (wisdom), 'aml (actions), haqq (truth), nuṭq (logic), types (soul), qalb (heart), 'aql (mind), marātib (degrees - order hirarkhis), āyat (symbol), and adab (manners). Therefore, the understanding of $t a ' d i b$ is much broader basis more comprehensive because shall cover the aspects those attitudes and behaviors conversion of a person or a group in maturing man through teaching and training (al-Attas, 1996: 66).

${ }^{28}$ Imam Musthofa \& Ally, Sejarah Pendidikan Islam: untuk Fakultas Tarbiyah Komponen MKDK (Bandung: Pustaka Setia,1999), p. 60.

${ }^{29}$ Zuharini, et al., Sejarah Pendidikan Islam (Jakarta: Bumi Aksara \& Dirjen Bagais Departemen Agama RI, 2004), p. 40.

${ }^{30} \mathrm{Ahmad}$ Tafsir, Metodologi pengajaran agama Islam (Bandung: Remaja Rosda Karya, 2002), p. 24.
} 
Philosophically, the concept and theory of Islamic educational were built or understood and developeded from the Qur'an and sunnah tenets which gained justification and oppresionally implementation in the process of cultivation, inheritance and development about the religion teachings, culture and Islamic civilization handed down from generation to generation that took place in history of mankind. On the basis of such understanding and conceptual framework, so various studies on Islamic education are always begun and departed two concepts, concept of human beings and concept of education. Having been developed from the Qur'an and al-Sunnah, faith and doctrine of tawhid (the oneness of Allah) is always coloring and underlying every concepts and practices of Islamic education. Tauhid in Islamic's view is a basis for the entire deeds of Muslims, both vertically and horizontally relationship. This reality made education in Islamic perspective has particular characteristics, because education (Islam) has been guided by transcendent sources, that is revelation (theosentrism). it does not mean Islamic education must be separated from the community, instead it embeds with it. This means that education (Islam) is an integral part of the community itself or even further, especially from the perspective of implementation which it needs to be developed and arranged in accordance with the situation and the need of community. Thus islamic education will be in accordance with essence the teachings of Islam itself, which is regarded as rahmatan li 'l-'ālamìn.

Islamic education Ideally tried to bring people reaching personal equilibrium as a whole to achieve world and hereafter happiness. In iddition in broader sense of Islamic education goal is to form a human who realizes and carries out the tasks of kekhalifahan and enrich themselves with the rich of science without getting to limit, but he should be also realized that true essence of a whole lives and proprietary of knowledge are coming from Allah. ${ }^{31}$ Zakiah Daradjat, et al.32 called that human with the term "perfect man" (insān kāmil), a physical and spiritual completed figure, who can live and grow in a reasonable and normal way because his fear (taqwā) to Allah,

\footnotetext{
31Muslih Usa, Pendidikan Islam di Indonesia: Antara Cita dan Fakta (Yogyakarta: Tiara Wacana, 1991), p. 9.

32Zakiah Daradjat, et al, Ilmu Pendidikan Islam (Jakarta: Bumi Akasara \& Direktorat Jenderal Kelembagaan Agama Islam Departemen Agama, 2004), p. 29.
} 
the Almighty. This means that Islamic education is expected to produce human beings that are useful for himself and the community as well. He is pleased and eager to practice and develop the teachings of Islam in our relationship with God and human beings. he can take advantage and benefits from natural resources for the sake of human interest both the world and hereafter.

Because it was formed and developed from the Qur'an and Hadith, there is a fundamental difference between aim of Islamic education and education system that developed from philosophy or antropsentric-rational values. Human is sn entity blessed with various perfect potencies (gift); both physically and spiritually, souls and minds, nafs and qalb. Many of potential perfections given by God to man has to be able to be changed or transformed into actus (actual perfection) through educational activities. Thus the aim of Islamic education is to change and made an potentially instrument and basic potential belonged to human into actual deeds, so they can to carry out the mandate of Allah either as khalīfatullāh fi 'l-ard or as 'abdullāh. The aim of education Islam requiered a coherent relation between the physical (physically, human is gifted) and the spiritual dimension (bāținiyyah), between the life of this world and the hereafter (li sa'ädat al-dārayn), and between individual and collective interests, between his position as khalifatullăh and duties as a slave. According to Hasan Langgulung33 the aim of Islamic education is the purpose of human life itself. And duty of education is to keep and protect human life. Based on such understanding, study about Islamic education must involve understanding of human nature and purpose of life itself in Islamic's view.

\section{Madrasah: Religious-based Character Education Model}

The mission of the apostolic Muhammad is to reform and to improve Jahiliyah Arabic morals by System of Islamic belief which is sourced from Allah revelations. It is began by faithfulness development (faith) as foundation for Muslim behavior, both in vertical relation (religious service) with Allah

\footnotetext{
${ }^{33}$ Hasan Langgulung, Manusia dan Pendidikan: Suatu Analisis Psikologi dan Pendidikan Oakarta: Pustaka al-Husna, 1986), p. 10.
} 
neither with fellow being and universe environment (mu'amalah). In Islamic concept, precious morals (akhlāq al-karimah) is accumulation and culmination from implementation of precept comprehension (shari'ah) which is based with sturdy faithfulness foundation (faith). A Muslim who has strong faith certainly will obey all of Islam provisions (precept) by doing rule of religion and leaving all of religion prohibition, they called taqwā. By keeping all of intact religion provisions ( $k a \bar{f} f f a h$ ), a Muslim will has precious morals like as practiced by Muhammad. Thereby, religion as guide and life system is very important for character building and human moral, both in vertical and horizontal dimension.

As a guide and life system, religion includes line of reference norm (include command and prohibition) which must be known, understood, inspired and worked. To extend step of work command and leave prohibition, a Muslim must to learn (to know, understand, has positive perception and at least do it). To exceed and attain those steps need media and methods. Education (formal) is the answer, because of that may be more effective and measured in transfer of knowledge, transfer of values and internalization value process. Nevertheless, informal and non-formal education institute have been important and strategy character to support formal education success. The synergy from three kinds of education will establish nation character building attainment. On the basis of framework and comprehension so make all of education level compulsory to teach religion in the learning system is very exact used in this nation as effort to attain education purpose (faithful, pious and good moral). For Islam learner, a course in the school named as Islamic Education (PAI).

In curriculum perspective, PAI considered as a course which has important role to comprehension and awareness to Islam values and religion etiquette for learner. Contents of PAI contains moral value and religion etiquette post PAI to out-position in moral development or student heterogeneous. This case is implied to demands of PAI's teacher task, all at once, become more roles in religion value resuscitation. As the course, PAI has some characteristic, namely: (1) PAI is a course that develops from Islam primary precepts; (2) PAI aims to build learner in order to believe and pious to Allah, along with precious moral; (3) PAI includes three primary frame- 
work, that is faith, syariah and morals (the Ministry Rule of National Education Number 22 Years 2006 about Content Standard). Based on that characteristic so PAI different clearly than other courses, because PAI's content is propriety values and beneficence (beauty too) derive from revelation. PAI's values are included in three primary framework PAI that must mastery to do and/or be life value that hold on. Start from primary framework and characteristic so the purpose or learning PAI competence in the school (SMA) that is: (1) understand al-Quran verses that relate with human function as leader, democracy with science of knowledge and technology development; (2) improve the faithful to Allah for qaḍa and qadr through comprehension to characteristic and Asmā' al-Husnā; (3) implement good attitude such as husn al-zann, tawbat, rajā', and leave bad attitude such as israf, tabdhir and fitnah; (4) understand Islam law source and taklifi law with explain mu'amalah law and family law in Islam; (5) understand the history of Prophet Muhammad on Makkah period and Medina period along with Islam development in Indonesia and in the world (National Education Department Standard Competence Graduate 2006).

Although the nomenclature is same but the PAI's content belonged to school and madrasah is too different, in term of the vastness and deepness of explanation. at school, PAI is given in a single course packet that taught by one teacher which is called religion teacher. Meanwhile in Madrasah, PAI is course field that described into five courses which taught by different teachers. Of course, that case is consequence to duration and frequency in the meet of learning. That courses consist of: (1) Qur'än- Hadìth, (2) 'Aqïdah Akhläq, (3) Fiqh, (4) Islamic Culture History, and (5) Arabic Language. ${ }^{34}$ To give description more intact about purpose or competence of result of course study to PAI's field that is taught in all of Madrasah education levels, here are samples of competence formula or PAI's field learning aim in Islamic Senior High School (MA).

1. Al-Qur'ān - Hadith. This course is to stimulate learners being fond of read al-Qur'än and Hadìth correctly along with learn, understand, believe the

\footnotetext{
${ }^{34}$ Such curriculum structure and composition like this was began in 1994, which named with "curriculum 1994". Islam religion course is given before based on decrre of Religion Ministry Number 110 1982, namely: (1) al-Qur'ān-Hadīth, (2) Arabic language, (3) Faith, (4) Religious service, (5) Morals, (6) Fiqh, (7) Islam History and Civilization.
} 
truth, and do precepts and values that contain in it as guidance and orientation in all of life aspects. The spaceroom of al-Qur'an Hadith course explanation covered: (a) 'Ulūm al-Qur'ān and Ulūm al-Hadìth, (b) Specific al-Quran verses that dished sistematically and specific Hadis that supported al-Qur'an verse.

2. 'Aqìdah Akhlāq. It develops and improves learners faith which implemented in good morals through gift and knowledge prosperous, full comprehension, implementing along witth learner implementing about faith and moral of Islam until become a Muslim human who more develop and more improve faith quality and piety to Allah and do prosperious moral in individual, society, nation and state. The spaceroom of 'Aqīdah Akhlāq course study field is: (a) 'Aqīdah aspect, (b) Akhlāq aspect and (c) role model history aspect.

3. Fiqh. It Provides learner to: (a) know and understand principles of Islam law comprehensively and in detail, consist of naqly and 'aqly theorems. The knowledge and comprehension be to be life orientation in individual and social life; (b) implement and carry out rule of Islam law correctly. That implementation to be grow loyalty to do Islam law, discipline and high social responsibility in individu neither social life. The space room of Fiqh discussion in MA consist of aptitude, harmony and balance among: (1) human relation with Allah; (2) humankind interrelationship; (3) human relation with universe (except human) and environment.

4. History of Islamic Culture (SKI). (a) it gives knowledge about history of Islam and its culture to learners so that it gives objective and systematic concepts in historical perspective; (b) it takes i'tibār, value and mean which is been in history; (c) it implants total comprehension and strong desire to apply Islam precept based on carefulness of fact history; (d) it builds learner personality become more virtuous based on history figure who deserved to be role model. Different with curriculum 1994 where SKI learning just comprehended as the history of Islamic culture, in KTSP curriculum 2006 SKI is being understood as the history of Islam and Islamic culture. Because of that, this curriculum does not only show history of authority or kings' history but also it appoints the history of religion knowledge development, science and technology in Islam. The history actor who is appointed not only a prophet, companions and 
caliphate but also completed with muslim scholars (ulama), intellectual and philosopher.

5. Arabic language. It encouraged learner to develop some aspects of their: (a) listening, speaking, reading and writing competence; (b) communication skills to speak simply but effective in various context to deliver information, idea and feeling along with braid social relation in various, interactive and gratifying activities; (c) ability to interpret various simple short text content and respond in various, interactive and gratify activities; (d) capacity of creative written although it is short and simple in different kind of text to deliver information, reveal idea and express feeling; (e) comprehend and appreciate belles-lettres; (f) skill on vocabulary mastery agreed with specific target that programmed to comprehend precept source text (al-Qur'an - al-Sunnah); (g) ability to speak arabic receptively or expressively. The space room of Arabic language in MA consist of: (1) language element; text form (șarf), sentence structure (naḥw), vocabulary (mufradāt); (2) language activities; reading (qirā'ah), speaking and writing.

Despite discussion course has been relatively wider and deeper than SMA has, almost in all of private Madrasah still more added with some summarized courses in local content or "local curriculum". It means learning process with religion content/course in Madrasah more extensive, depth and wide than in the school. This means opportunity of transformation result and religion value internalization to attain educatian aim (faith, piety and prespious moral) is bigger than the school. extra courses particularly related with assisting knowledge (device knowledge) to support religious competence result, such as: naḥwu/șaraf, 'ulūm al-Qur'ān, 'ulūm al-Hadìth, ușūl al-fiqh, etc. These courses are aimed to deepen and enrich religion knowledge (science) agreed with specific vision-mission and to attain specific Madrasah purpose, that is religious competence. ${ }^{35}$ This fact can be understood because context of Madrasah birth can not separated from da'wah Islämiyyah. As example, to

\footnotetext{
${ }^{35}$ Religion competence that means here is specific competence that has by learner to involve actively in religious activity (religious ritual) in the village. By this competence, so MA graduation will have readiness to: (1) continue to university level with PTAI as option, and, (2) enter in society become religion figure or religious activity leader in society environment where they live.
} 
attain that competence beside national curriculum (based on SI and SKL) MA Qudsiyah Kudus (and some other MA in Kudus) added a number of religion course ('ulüm al-dīn) that attach in local curriculum with same learning system even same with system in Islamic boarding school. Kind and total of course along with book that became reference can look into tabel below.

Courses List

Local Curriculum of MA Qudsiyah Kudus

\begin{tabular}{|c|c|c|}
\hline No. & Courses & Learning Reference Book \\
\hline 1 & Tafsir al-Qur'an & Tafsīr Jalālayn \\
\hline 2 & Ilmu Tafsir & Tashrih al-Yasir \\
\hline 3 & Ilmu Qira'ah & - \\
\hline 4 & Hadits & Bulūgh al-Marām \\
\hline 5 & Musthalah al-Hadīts & Musthālāḥ al-Hadīth \\
\hline 6 & Tauhid & Tuhfat al-Murīd \\
\hline 7 & Akhlāq & Qifāyat al-Atqiyā' \\
\hline 8 & Mantīq & Sulam al-Munawwarah \\
\hline 9 & ASWAJA doctrine & Farā'idus Sanniyyah wa Durār al-Bahiyyah \\
\hline 10 & Fiqh & Takhrīr \\
\hline 11 & Ushul Fiqh & Lubāb ul-Ușūl \\
\hline 12 & Qawā'id al-Fiqhiyah & Hidāyah al-Ṭābah \\
\hline 13 & Falak Lugharitma & $\begin{array}{l}\text { 1) Durūs al-Falaqiyah } \\
\text { 2) Lughārițma }\end{array}$ \\
\hline 14 & Nahwu - Sharaf & Ibnu 'Aqil-Șaraḥ Alfiyah \\
\hline 15 & Bahasa Arab & - \\
\hline 16 & Balaghah & 'Uqūd al Jumān \\
\hline 17 & Muțala'ah & Specific book study \\
\hline 18 & Qirā'ah Sab'ah & Faid al-Sani \\
\hline
\end{tabular}

Referring to all of definitions about character education concept and see empirical reality that Madrasah education institute -with curriculum structure (national and local) and learning purpose- exactly is character education model or education based character that has been and we are having up till now. So Why we must to look for model reference of character education from western that didn't certain same in value concept yet with we want? Education is fundamentalism problem to the nation that always and certain relate with culture, perception even society belief. Because of that, education professionals agreed that system with education purpose to society 
or country cannot to import or export from the country or the society. In Azyumardi Azra definition, education should grow and "sewed" agree with user's shape and measure, based on identity, life paradigm along with values in society or country. So there is no education concept and theory that obtain or can to apply comprehensively, in other means can obtain to different place and setting. ${ }^{36}$

Madrasah less has showed its charm to urban people up till now (read: well inform and well educated), we should admit that is right honestly. Unattractiveness or even distrust of particular society group to Madrasah more caused by their perception and faithful that this education institute less progressive in common course learning (read: science), so it decreased opportunity to win competition in grabbing opportunity to get further educational level. The less quality process and learning result is just because best part of Madrasah confront some weaknesses particularly finance aspect and human resource quality. This fact happened because nationally $85 \%$, Madrasah has been managed by community (private) and majority it is in rural area. That case happened because Madrasah as education institute came rather late to be appreciated (read: admitted the existence), because politically Madrasah and Islamic boarding house in their era became unseparated part from struggle to fight colonialism and imperialism. We must admit that schooling education system that we pliant now is an inherit ant of schooling system introduced by Dutch to indigene. Therefore, since colonialism era until first independence era, school and Madrasah seemed have their own method and way although substantive purpose is same educate nation.

If Madrasah is managed finely and correctly, actually it will be "plus" educational institution and character education model that agree with Indonesia culture needed by this nation, that is to build nation character with faithful, pious and good moral (Islam archipelago). And the most important is curriculum composition like right now added learning model that agree with Islam Archipelago, the learners will get Islam comprehension which more tolerant and appropriate with archipelago (Nusantara) concept that is plural

36Abudin Nata, Metodologi studi Islam (Jakarta: Rajagrafindo Persada, 1999).

Tawasut - ISSN 2338-042X - Vol 5, No 1 (2017) 
and multicultural. The equilibrium between cognitive result and character building through religion education and all of courses by synergy also can be an answer for all of state problems which lied on low of morality and intolerant attitudes. Honestly it must admitted, mathematic targets of education result, neglecting and isolating any etiquette values of suspension and religion morality systematically were losing and discounting purpose and holistic values the education process.

The problem now is how political will and/or political action which will be taken in to implement a model of character education. To assure character education in the school (general) to be more effective, deservedly curriculum of Islam religion education (SD, SMP, and SMA/SMK) rearranged to ascertain education result (faith, pious and good moral) can achieve finely in accordance with the condition of Islam Nusantara (Indonesia archipelago). The way that can be taken in which trough PAI reinforcement, it means learning duration and frequency must be improved either quality or quantity. Because PAI learning in the school so far has been too concise and limited so it seems formality only. That situation systematically had made religion as only knowledge that didn't make positive correlation with attitude. Even it often cause less proportional comprehension and perception that reflected in heterogeneous member. Because of knowledge achievement less depth and wide, it will cause wrong perception which resourced to wrong action intolerant, exclusive, extreme and radical. To attain education result in attitude form (behavior), we need knowledge internalization process and value through strategy of habituation. Various facts showed PAI learning in the school like present will difficult to build character and to produce precious moral because the learning is implemented very limited on frequency and duration. In the other word, PAI learning nowadays in quality and quantity is very insufficient to habituation and model process.

Therefore, quality and quantity improvement of PAI learning in the school became a very rational concept to implement. What kind of curriculum structure model which is suitable to implement in the school in order to achieve an education result which could produce personalities with wellcharacterized and preciouses moral output? In accordance with empirical facts and analysis above so optional policy that can be taken by government is 
restructuration and reconstruction curriculum adapting curriculum model which for a long time has been implemented at Madrasah. The important point that can be taken from Madrasah curriculum is a balanced curriculum composition between general knowledge (science) and religion knowledge. By such curriculum model and supported by appropriate learning system/ model we should optimize what we wanted in national education purpose formula will be achieved.

\section{Conclusion}

Based on elucidation above, it can be inferred as follows:

First, the emergence of phenomenon extreme-radical understanding and behavior in the name of religion is a result of understanding and the perception that is not proportional upon norms or religious doctrines. It can be happened because there was a mistake in the process of transmission and reception of religion doctrines.

Second, compatibility of educational process with students condition will guarantee an understanding and building of positive perception toward religion tenets which will boost a productive religiousity.

Third, a productive Religiosity will be able to become an internal power which is so effective as an instrument to choose, filter and prevent a possibility of negative impact coming from outside which is not in line with essence of islamic teachings, that is rahmatan li 'l-'älamin.

Fourth, as a concept, character education and moral education, viewed from its substances and purposes, have a common aspect, that both are aimed to build his character or moral of nation's young generation. Referring to purposes of national education system, the central orientation referred as a base and aim of characters education are values and virtues coming from the religion's teachings. This means that character which want to be formed is about character based on religion-faith, fear to God and a high moral standards.

Fifth, Madrasa educational system is a model of character education that is suitable for Indonesian conditions. Empirically this educational institution has 
succeeded in educating people with spirit of Indonesia Islam, which is moderate, tolerant - Nusantara Islam.

Sixth, there must be a polical will from the government to help and to empower madrasah from a number of weaknesses, especially facilities and funding problems. Indeed it really needed To strengthen and improve productivity of madrasah as a exemplary and model of religious-based character education.]

\section{Bibliography}

Ali Imron, Kebijakan Pendidikan di Indonesia: Proses Produk dan Masa Depannya, Jakarta: Bumi Aksara, 1996.

al-Attas, S.M.N., The Concept of Education in Islam: A Framework of an Islamic Philosophy of Education. Kuala Lumpur: Muslim Youth Movement of Malasyia, 1996.

Allport, G.W., Pattern and Growth of Personality, New York: Holt, Renehart and Winston, 1964.

Arsohah, H., Sejarah pendidikan Islam, Jakarta: Logos, 1999.

Azyumardi Azra, Surau: Pendidikan Islam Tradisional dalam Transisi dan Modernisasi, Jakarta: Logos, 2003.

Bloom, Benjamin S., etc., Taxonomy of Educational Objectives: The Classification of Educational Goals, Handbook I Cognitive Domain, New York: Longmans, Green and Co., 1956.

Brown, E.D., Organisational Culture, London: Prentice Hall, 1989.

Burhanudin, J. \& Dina A., (eds.), Mencetak Muslim Modern: Peta Pendidikan Islam Indonesia. Jakarta: Raja Grafindo Persada, 2006.

Departeman Pendidikan Nasional, Kamus Bahasa Indonesia. Jakarta: Balai Pustaka 1995). Peraturan Menteri Pendidikan Nasional No. 22 Tahun 2006 tentang Standar Isi.

Peraturan Menteri Pendidikan Nasional No. 23 Tahun 2006 tentang Standar Kompetensi Lulusan. 
Depertemen Agama RI, Keputusan Menteri Agama No. 370 dan 373 Tahun 1993 tentang Kurikulum MI, MTs, MA.

Sejarah Madrasah: Pertumbuhan Dinamika dan Perkembangannya di Indonesia. Jakarta: Direktorat Jendral Kelembagaan Agama Islam, 2004. , Buku Pedoman Khusus Pendidikan Agama Islam. Jakarta, 2002.

Panduan Kurikulum 1994 Madrasah. Jakarta: Depag RI., 2004.

Djatmika, Rahmat, Sistem Ethika Islam, Jakarta: Pustaka Panjimas, 1996.

Echols, John M. dan Hasan Sadily Kamus Inggris Indonesia, Jakarta: Gramedia, 1987.

Fakry Gaffar M., "Pendidikan Karakter Berbasis Islam”, Yogyakata, seminar papers, 8-10 April 2010.

Fullan, M.G., The New Meaning of Educational Change, England: Cassell Educational Limited, 1991.

Goleman, Daniel, Emotional Intelligent (Kecerdasan Emosional), translated by T. Hermaya, Jakarta: Gramedia Pustaka Utama, 1997.

Langgulung, Hasan, Manusia dan Pendidikan: Suatu Analisis Psikologi dan Pendidikan, Jakarta: Pustaka al-Husna, 1986.

http// www.chracter.org. download 02-05-2013.

http//www. Wikipedia Encyclopedia.

Jalal, A.F., Min Ușūl al-Tarbiyah fi I-Islām, Kairo: Dār al-Kutub al-Mișriyyah, 1977.

Josephson, M., Making Ethical Decisions: the Six Pillars Character Education, New York: Josephson Institute, 2013.

Kadir, Muslim A., Dasar-dasar Praktikum Keberagaman dalam Islam, Yogyakarta: Pustaka Pelajar, 2011.

Kesuma, Dharma, dkk., Korupsi dan Pendidikan Anti Korupsi, Bandung: Pustaka Aulia Press, 2011.

Koesoema, Doni Pendidikan Karakter: Strategi Mendidik anak di Zaman Global. Jakarta. Grasindo, 2007.

Kohlberg, L, The Development of Children's Orientation toward Moral Order: Sequence in the Development of Moral Though. Vita humana, 1963.

Tawasut - ISSN 2338-042X - Vol 5, No 1 (2017) 
Kupperman, J.J., The Foundation of Morality. London: George Allen and Unrwin, 1983.

Lickona, Thomas, Educating for Character: How Our School s can Teach Respect and Responsibility, New Yok, Toronto. London. Sydney, Auckland: Bantam Books, 1991.

Maksum, Madrasah: Sejarah dan Perkembangannya. Jakarta: Logos, 1999.

Muslih, Masnur Pendidikan Karakter: Menjawab Tantangan Krisis Multidimensional, Jakarta: Bumi Aksara., 2011.

Muhaimin, et.al. Paradigma Pendidikan Islam: Upaya Mengefektifkan Pendidikan Agama Islam di Sekolah. Bandung: Remaja Rosdakarya, 2002.

Musthofa, A. \& Aly, A., Sejarah pendidikan Islam: Untuk Fakultas Tarbiyah Komponen MKDK. Bandung: Pustaka Setia, 1999.

Muhadjir, Noeng, Ilmu Pendidikan dan Perubahan Sosial: Teori Pendidikan Pelaku Sosial Kreatif, Yogyakarta: Rake Sarasin, 2000. Metodologi Penelitian Kualitatif, Yogyakarta: Andi Ofset, 2002. Metodologi Keilmuan: Paradigma Kualitatif Kuantitatif dan Mixed, Yogyakarta: Rake Sarasin, 2007.

Nata, Abudin, Metodologi Studi Islam, Jakarta: Rajagrafindo Persada, 1999.

Peraturan Pemerintah No. 29 Tahun 1990 tentang Pendidikan Madrasah Aliyah.

Peraturan Pemerintah No. 55 Tahun 2007 tentang Pendidikan Keagamaan.

Peraturan Pemerintahan tentang Pelaksanaan Undang-Undang No. 2 Tahun 1989 tentang Sistem Pendidikan Nasional Jakarta: Armas Duta Jaya, 1990.

Ratna Megawangi, Pendidikan Karakter: Solusi yang Tepat untuk Membangun Bangsa, Bogor: Indonesia Heritage Foundation, 2004.

Romiszowski, A.J., Producing instructional System: Lesson Planning for Individualized and Group Learning Activities, London: Kogan Page Ltd., 1984.

Ryan, K. \& Bohlin, K.E. Building character in Schools. Practical Ways to bring Moral Instruction to Life. San Francisco. Jossey Bass, 1999.

Sa'id, Muka, Etika Masyarakat Indonesia, Jakarta: Pradnya Paramita, 1986. 
Seidman, E., Handbook of Social Intervention. Beverly Hill/London/New Delhi: Sage Publication, 1983.

Steenbrink, K.A., Pesantren Madrasah Sekolah: Pendidikan Islam dalam Kurun Modern, Jakarta: LP3ES, 1994.

Suwito \& Fauzan, (eds.), Perkembangan Pendidikan Islam di Nusantara: Studi Perkembangan Sejarah dari Abad 20 M. Bandung: Angkasa, 2004.

Suyanto, Urgensi Pendidiklan Karakter, Jakarta: Direktorat Jenderal Manajemen Pendidikan Dasar dan Menengah, 2009.

Tafsir, Ahmad, Metodologi Pengajaran Agama Islam. Bandung: Remaja Rosda Karya, 2002.

Tajab, et.al., Dasar-dasar Kependidikan Islam: Suatu Pengantar Pendidikan Islam. Surabaya: Karya Aditama, 1996.

Usa, Muslih, Pendidikan Islam di Indonesia: Antara Cita dan Fakta, Yogyakarta: Tiara Wacana, 1991.

Undang-Undang RI No. 02 Tahun 1989 tentang Sistem Pendidikan Nasional.

Undang-Undang RI No. 20 Tahun 2003 tentang Sistem Pendidikan Nasional.

Webster's New Dictionary and Thesaurus, New Lanark-Scotland: Geddes \& Grosset Ltd., 1990.

Windham, Douglas M., Improving the efficiency of educational systems: Indicator of educational effectiveness and efficiency, New York: United State Agency for International Development Buereau for Science and Technology, 1990.

Woolfolk, Anita E. and Nicolich, Lorine Mc Cune (1980). Educational Psychlology for Teachers. Prentice-Hall Inc. Englewood Cliffs. New Jersey.

Ya'kub, Hamzah, Etika Islam: Pembinaan Ahlakul Karimah (Suatu Pengantar), Bandung: CV. Diponegoro, 1988.

Zakiah Daradjat, etal., Ilmu Pendidikan Islam. Jakarta: Bumi Akasara \& Direktorat Jnendral Kelembagaan Agama Islam Departemen Agama, 2004.

Zins, Joseph, et.al,, Emotional Intelligence and School Success, New York: Phi Delta Kappa, 2001.

Zuhairini, et al. Sejarah Pendidikan Islam. Jakarta: Bumi Aksara \& Dirjen Bagais Departeme Agama RI, 2004. 
